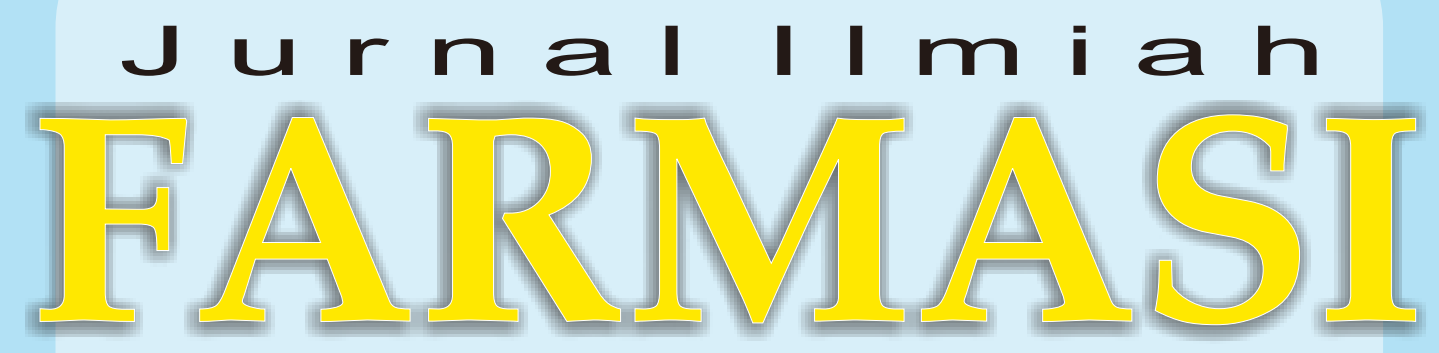

(Scientific Journal of Pharmacy) 
JURNAL ILMIAH FARMASI

(SCIENTIFIC JOURNAL OF PHARMACY)

PIMPINAN UMUM/ PENANGGUNG JAWAB

Dekan Fakultas Matematika dan Ilmu Pengetahuan Alam

Universitas Islam Indonesia

WAKIL PIMPINAN UMUM/ WAKIL PENANGGUNG JAWAB

Ketua Jurusan Farmasi FMIPA UII

\section{MITRA BESTARI}

1. Prof. Dr. Wiryatun Lestariana, Apt

2. Prof. Dr. Zullies Ikawati, Apt

3. Prof. Dr. Sudibyo Martono, Apt

4. Dr. Tedjo Yuwono, Apt

5. Prof. Dr. Dachriyanus, Apt

6. Prof. dr. Iwan Dwiprahasto, MMedSc, PhD

7. Prof. Dr. Lukman Hakim M.Sc., Apt

8. Prof. Dr. Achmad Fudholi, DEA, Apt

9. Prof. Dr. Ibnu Gholib Gandjar, DEA., Apt

\begin{tabular}{ll} 
& \multicolumn{1}{c}{ DEWAN EDITOR } \\
Ketua & : Saepudin, M.Si., Apt \\
Sekretaris & : Rochmy Istikharah, M.Sc., Apt. \\
Anggota & : Vitarani Dwi Ananda Ningrum, M.Si., Apt \\
& Okti R. Mafruhah, MSc., Apt \\
& Dimas Adhi Pradana, MSc., Apt. \\
& Fithria DA. Suryanegara, MSc., Apt. \\
& Ari Wibowo, S.Farm., Apt \\
& Arba Pramudita Ramadani, MSc., Apt. \\
& Oktavia Indrati, S.Farm., Apt.
\end{tabular}

Penerbit

Jurusan Farmasi Fakultas Matematika dan IImu Pengetahuan Alam Universitas Islam Indonesia

Alamat Penerbit Jurusan Farmasi FMIPA UII

Jl. Kaliurang Km. 14,4 Yogyakarta 55584

Telp. (0274) 896439 ext. 3047

Email: jif@uii.ac.id 


\title{
EVALUASI POTENSI PELESTARIAN TUNAS HASIL KULTUR IN VITRO DARI TANAMAN OBAT CEPLUKAN (Physalis angulata,L.)
}

\section{Saepudin}

\author{
Program Studi Farmasi Universitas Islam Indonesia
}

\begin{abstract}
A tissue culture and plant generation for the ceplukan, Physalis angulata, $\mathrm{L}$ has been developed. Callus were efficiently induced on Murashige and Skoog (MS) medium supplemented with 0,1 ppm indole-3-acetic acid (IAA) and variation of 1, 2, 3, 4, and 5 ppm benzyladenine (BA). The regenerable callus differentiated into shoots. Phytochemical containing of the shoots were detected and compared with the origin plant using Thin Layer Chromatography (TLC). Flavonoid was showed by bright blue spot under UV $366 \mathrm{~nm}$ and became yellow after smoked by NH3 with HRf 43 and 69. Saponin was showed by yellow spot with HRf 18 and purple spot with HRf 45 after sprayed by anisaldehyde-sulfuric acid. HRf of the shoots from culture and origin plant were the same, showed that shoots contains the same phytochemical as the origin plant.
\end{abstract}

Keyword: shoots, tissue culture, restoration, flavonoid, saponin 